UDC 631.45

(C) 2020

\title{
Keep the soil alive, protect soil biodiversity
}

\author{
Baliuk S. ${ }^{1}$, Medvedev V. ${ }^{2}$, Momot H. ${ }^{3}$, Levin A. ${ }^{4}$ \\ National Scientific Center «Institute for Soil Science and Agrochemistry Research named after O.N. \\ Sokolovsky» \\ 4 Chaikovska Str., Kharkiv, 61024, Ukraine

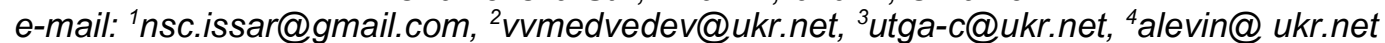 \\ ORCID: ${ }^{1} 0000-0002-8372-6514,{ }^{2} 0000-0001-7319-8773,{ }^{3} 0000-0003-3944-7689,{ }^{4} 0000-0002-9346-$
} 2735

Goal. To analyze the current state of soils of Ukraine, to substantiate the measures of legislative, regulatory, scientific, and information support of balanced land use to overcome soil degradation using the international experience of soil protection and land use. Methods. Analysis, synthesis, theoretical generalization and comparison, abstract, monographic, expert. Results. The results of the study of ways to overcome soil degradation to ensure balanced land use, namely: a repeated continuous soil survey (or adjustment); soil cover monitoring taking into account European experience; improvement of the national system of agrochemical certification of agricultural lands; legislative and regulatory support of soil protection; improvement of information support due to the formation of soil databases with expanded assessment, cartographic and forecasting capabilities for the functioning of the Ukrainian Soil Information Center; development and adoption of the National Soil Protection Program and regional soil protection programs; creation of the State Service for Soil Protection and Monitoring; improvement of the quality assessment of soils and determination of the objective price of land; actualization of scientific research in soil protection, their material, and technical support; use of international experience in soil protection and land use. Conclusions. The country has every opportunity to create an exemplary system of soil resources management and implement to the best the provisions of the Constitution of Ukraine, which recognizes lands (soils) as national property under special state protection. This requires reformation of the system of state control over the condition of soils and regulation in the field of soil protection and their fertility, elaboration of the new state policy, as well as and development and adoption of a new strategy for the development of land protection in Ukraine until 2030.

Key words: sustainable soil management, soil fertility, soil degradation, soil protection, soil monitoring, balanced land use.

DOI: https://doi.org/10.31073/agrovisnyk202012-01

At the initiative of the participants of the World Congress of Soil Science, which took place in Bangkok (Thailand), 5 December is marked as World Soil Day. It honors the memory and achievements of the world-famous scientist Vasily Vasilyevich Dokuchaev. On this day in 1883 he defended his doctoral dissertation "Russian chernozem". Soil is a natural resource and it is not restored for a human lifetime. It is rightly called the main wealth of the planet. V.V. Dokuchaev defined the soil as the "Fourth Kingdom of Nature." However, due to the implementation of unbalanced deficit systems of agriculture with intensive use of soil cover, the challenge of soil degradation is growing from year to year.

Today, World Soil Day is celebrated annually by decision of the 68th session of the UN General Assembly as a way to focus on the importance of soil protection and management and sustainable management of soil resources.

In 2020, the celebration of World Soil Day is held under the theme "Keep the soil alive, protect soil biodiversity."

The purpose of research -analysis of the current state of soils of Ukraine, substantiation of measures of legislative, normative-legal, scientific, information support of balanced land use and overcoming soil degradation with the use of international experience of soil protection activity and land use.

Materials and methods of research. The results of long-term research presented in scientific publications, regulatory framework for soil protection, statistical data, etc were processed. Research methods - analysis, synthesis, theoretical generalization and comparison, abstract-logical, monographic, expert.

Research results. The results of the analysis of recent research and publications show that currently the issue of sustainable soil management is being actively studied by foreign scientists. Following the adoption of the revised World Soil Charter, the Global Soil Partnership (GSP) developed the Voluntary Guidelines for Sustainable Soil Management (VGSSM) and they were endorsed by FAO and its member countries. Sustainable soil management in production conditions means that "soil functions contribute to ecosystem services and biodiversity, natural and economic resources are used efficiently, agriculture remains profitable, and production conditions meet ethical and health standards" [1]. Investigating the issues of soil management, scientists consider various aspects of soil degradation and sustainable intensification of agricultural production to achieve sustainable development goals at the global, national, 
regional and local levels [2, 3]. Other scientists study the tools of sustainable soil management: soil ecosystem services, energy and economic analysis [4]; assess the quality of soils for sustainable land use and management [5]; study the level of farmers' knowledge on soil quality and methods of its fertility management [6, 7]; analyze the possibility of using consulting services to support sustainable soil management [8].

Ukrainian scientists study a wide range of issues, such as: the role of soil in the development of society [9]; ecological state of soils of Ukraine [10]; geography, genesis and current state of chernozems of Ukraine [11]; assessment of economic losses from soil degradation [12]; formation of sustainable land use and soil protection systems in modern conditions [13]; soil fertility management based on innovative approaches to assessment of arable land [14].

Ukraine has a unique soil cover - more than $60 \%$ of its area is occupied by chernozem soils, which in their characteristics of the root layer, properties, fertility potential, suitability for growing many field crops are unmatched. Due to the great resource potential of natural fertility of chernozems, Ukraine occupies a leading position in world exports of cereals and sunflower. At the same time, in recent years Ukraine has been dominated by an unbalanced deficit system of agriculture with a gradual depletion of soil resource potential and deterioration of the ecological state of soils. As a result, soils have lost much of their humus, the most fertile soils in the world have become medium-fertile soils and continue to deteriorate. By the way, in countries where the leased form of land use dominates, as well as in Ukraine, there is a decline in soil fertility. It is unacceptable to maintain such an approach to fertility, as it will further aggravate the problem. Unfortunately, since the time of independence, systematic work on soil protection in Ukraine has not been established [15].

Many hopes were pinned on land reform. It was believed that the change of ownership of land would automatically form a responsible competent owner who would protect and increase soil fertility. However, it did not happen in real production. Now, under the conditions of opening of the land market there are big risks of strengthening of degradation of soils and deterioration of their fertility [16]. Therefore, it is necessary to reform the system of state control over the condition of soils and regulation in the field of soil protection and fertility, a new state policy, development and adoption of a new Strategy for the Development of Land Protection in Ukraine until 2030.

Due to incomplete land reform, almost complete irresponsibility of new land users renting land, poor land cadastre, ineffective level of legal protection of soils, lack and practical imperfection of soil fertility control - the country actually operates a chaotic type of land use with negative consequences for future generations.

Currently, the following issues are being discussed and need to be addressed in Ukraine:

- conducting a repeated continuous (or adjustment) soil survey, because the materials of the previous one, conducted more than 50 years ago, are outdated. The new survey should be conducted on new methodological principles, taking into account modern advances in geoinformatics, remote sensing, modeling, forecasting using modern software [17];

- organization of soil monitoring taking into account European experience [18], improvement of the national system of agrochemical certification of agricultural lands, which has been operating in the country since the 60 s of the last century, with the involvement of remote sensing. Combining new cartographic and analytical materials obtained as a result of repeated soil surveys with agrochemical certification and monitoring data will be the exemplary world level of information on the country's soils;

- legislative and normative-legal support of soil protection. Soil should be the object of law, protection, not just use;

-improvement of information support due to the formation of soil databases with expanded assessment, cartographic and forecasting capabilities, the functioning of the Ukrainian Soil Information Center, which was established on the basis of NSC ISSAR with the support of the Food and Agriculture Organization of the United Nations (FAO), the Global Soil Partnership (GSP), the National Academy of Agrarian Sciences of Ukraine, the Ministry of Economic Development, Trade and Agriculture of Ukraine, the Ministry of Environment and Natural Resources of Ukraine;

- development and adoption of the National Soil Protection Program, regional soil protection programs, programs of united territorial communities. It is necessary to use funds from the state, regional, local budgets and other sources;

- significant change in the management of land use and protection through the creation of the State Service for Soil Protection and Monitoring. Such a service in the United States covers the entire territory of the country, has detailed, periodically updated soil cartographic and analytical materials (conducted since 1972), monitoring of soil cover and research of mainly applied content;

- soil quality assessment, improvement of soil quality assessment and determination of the objective price of lands (normative monetary assessment), which is extremely important for the investment attractiveness of the country's lands;

- updating of scientific research on soil protection, their material and technical support;

- use of international experience of environmental (soil protection) activities and land use. There are many examples of progressive land use in the world that deserve to be studied and spread as much as possible in Ukraine.

In addition, it is very important to intensify the media in the soil protection aspect, especially television, where cognitive, educational and educational programs about soils are almost absent. Moreover, Ukraine 
needs to have and issue a bulletin on the state of Ukraine's soil cover once every 3-5 years (for reference: every 5 years the US Congress has a report on the general state of the country's soil resources).

In recent decades, a new understanding of soil as the most important ecological resource has been gradually established in the world [10]. Productive functions of the soil are supplemented by ecological functions, according to which the soil actively regulates water, air, thermal regimes of all adjacent environments - the surface layer of the atmosphere and soil, affects metabolism and energy, serves as a medium for many different organisms (biodiversity). It performs a number of vital functions, including social ones and the state of the agro-sphere, health and human well-being depend on them.

"Soil is a parabiotic (almost living) body" - these are the exact words by Academician O.N. Sokolovsky. It means the need to treat the soil as a living body.

With such the latest trends in agriculture, appropriate changes should be made in Ukraine, particularly in supporting soil protection information, deepening the content of the media, intensifying soil protection activities in social movements, improving education, especially training new leaders capable of perceiving and implementing soil protection information.

It should be noted that recently the active position of experts from international institutions has played a leading role in returning the issue of soil protection and conservation to the agenda at the global and regional levels, the adoption of relevant conventions, charters, strategies, programs. The contribution of Ukrainian specialists is noticeable in the implementation of these initiatives.

Ukraine actively cooperates with various international soil organizations. First of all, FAO with its welldeveloped infrastructure for the study and management of soils, GSP, created at the initiative of FAO, which main purpose is the sustainable management of soil resources. NSC "Institute for Soil Science and Agrochemistry Research named after O.N. Sokolovsky"- National Focal Point of Ukraine for Cooperation with the GSP, Baliuk S.A. - Head of the National Focal Point of Ukraine for Cooperation with the GSP. In recent years, with the support of FAO/GSP, the following have been prepared:

- national digital maps of organic carbon stocks in the soils of Ukraine as a component of the Global Map of Soil Organic Carbon; maps of saline and alkaline soils, soil reactions $(\mathrm{pH})$;

- Voluntary Guidelines for Sustainable Soil Management - translation into Ukrainian of the FAO/GSP manual:

- updated database of soil protection legislation of Ukraine as an integral part of the SoiLEX Global database on national soil protection legislation;

- International Code of Conduct for the Sustainable Use and Management of Fertilizers;

- Protocol for the Assessment of the Impact of Sustainable Soil Management Practices;

- FAO Report: State of Knowledge on Soil Biodiversity;

- Report on the Global Status, Current Production and Challenges in Black Soils.

Experts from Ukraine took part in international symposia - Soil Organic Carbon (2017), Soil Pollution (2018), Soil Erosion (2019), foreign internships on mapping, monitoring and others.

The International Training-Workshop on Saline Soil Management was held on the basis of the NSC ISSAR (2018). Active work is underway in the International Network of Black Soils, analytical laboratories (Glosolan).

There are works on international grants, joint projects, participation in the publication of a report on the Status of the World's Soil Resources, Soil Atlas of Europe, Handbook for Saline soil management, and others.

The following activities are planned in the long term:

- participation in global symposia - on Soil Biodiversity (2021), Saline Soils (2021), Soil Fertility (2022);

- preparation of cartographic materials - Global Soil Organic Carbon Sequestration Potential Map, maps of eroded lands, maps of the distribution of chernozem soils, etc.;

- preparation of relevant national sections for the 2nd version of the World's Soil Resources (2025), the Atlas of Soils of Europe, sustainable management of soil resources (2020-2021);

- participation in the International Network of Soil Information Institutions (INSII), the Global Soil Laboratory Network (Glosolan), the International network of Black Soils (2021, Ukraine, Kharkiv).

It is also desirable to intensify contacts with public organizations - ISTRO, ESSC, ESCO, NO RBA, IUSS, Soil and Society, ICLEI SOIL NETWORK etc.

The benefits of contacts with international institutions are obvious - free access to information, attraction of foreign experience, participation in various projects, grants and, finally, obtaining financial support.

European choice of Ukraine and future accession to the EU require the gradual transfer of the country's land use to the way of sustainable development and active implementation of the principles of the "European Soil Policy".

\section{Conclusions}

Ukraine has all possibilities to create an exemplary system of soil resources management and to implement the provisions of the Constitution, which recognized lands (soils) as a national property under special state protection. This requires reforming the system of state control over the condition of soils and 
regulation in the field of soil protection and fertility, a new state policy, development and adoption of a new Strategy for the development of land protection in Ukraine for the period up to 2030.

We hope that World Soil Day will unite all concerned people in the world for a noble cause - protection of our soils from depletion, destruction, degradation, consolidate the efforts of soil scientists, agrochemists, farmers, ecologists, land managers to conserve and reproduce soil fertility.

\section{References}

1. Helming, K., Daedlow, K., Hansjürgens, \& B. Koellner, T. (2018). Assessment and Governance of Sustainable Soil Management. Sustainability, 10, 4432. doi: 10.3390/su10124432

2. Osman, K. T. (2018). Management of Soil Problems, Springer International Publishing, XX. doi: 10.1007/978-3-319-75527-4

3. Ginzky, H., Dooley, E., Heuser, I. L., Kasimbazi, E., Markus, T., \& Qin, T. (Eds.). (2017). International Yearbook of Soil Law and Policy 2017. Springer International Publishing. doi: 10.1007/978-3-319-68885-5

4. Jónsson, J. Ö. G., Davíðsdóttir, B., Nikolaidis, N. P., \& Giannakis, G. V. (2019). Tools for Sustainable Soil Management: Soil Ecosystem Services, EROI and Economic Analysis. Ecological Economics, 157, 109-119. doi: 10.1016/j.ecolecon.2018.11.010

5. Adeyolanu, O. D., \& Ogunkunle, A. O. (2016). Soil Quality Assessment for Sustainable Land Use and Management. International Journal of Plant \& Soil Science, 13(6), 22136.

6. Ansong Omari, R., Bellingrath-Kimura, S. D., Sarkodee Addo, E., Oikawa, Y., \& Fujii, Y. (2018). Exploring Farmers' Indigenous Knowledge of Soil Quality and Fertility Management Practices in Selected Farming Communities of the Guinea Savannah Agro-Ecological Zone of Ghana. Sustainability, 10, 1034. doi: 10.3390/su10041034

7. Kuria, A. W., Barrios, E., Pagella, T., Muthuri, C. W., Mukuralinda, A., \& Sinclair, F. L. (2019). Farmers' knowledge of soil quality indicators along a land degradation gradient in Rwanda. Geoderma Regional, 16, e00199. doi: 10.1016/i.geodrs.2018.e00199

8. Ingram, J., \& Mills, J. (2019). Are advisory services "fit for purpose" to support sustainable soil management? An assessment of advice in Europe. Soil Use and Management, 35(1), 21-31. doi: 10.1111/sum.12452

9. Poznyak, S.P., \& Gavrish, N.S. (2019). Rol gruntiv u rozvytku suspilstva [Role of soils in the development of society]. Ukrainian Geographical Journal, 2, 57-61 [In Ukrainian].

10. Baliuk, S.A., Medvedev, V.V., Miroshnychenko, M.M., Skrylnyk, Ye.V., Tymchenko, D.O., Fateev, A.I., Khrystenko, A.O., \& Tsapko, Yu. L. (2012). Ekolohichnyi stan gruntiv Ukrainy [Ecological state of soils of Ukraine]. Ukrainian Geographical Journal, 2, 38-42 [In Ukrainian].

11. Poznyak, S.P. (2016). Chornozemy Ukrainy: heohrafiia, geneza i suchasnyi stan [Chernozems of Ukraine: geography, genesis and current state]. Ukrainian Geographical Journal, 1, 9-13 [In Ukrainian]

12. Kucher, A. V., Kucher, L. Yu. (2015). Expert assessment of economic losses caused by soil degradation at agricultural enterprises. Actual Problems of Economics, 8, 165-169.

13. Tarariko, O. H., llienko, T. V., \& Kuchma, T. L. (2016). Formuvannia stalykh system zemlekorystuvannia ta okhorony gruntiv: aktualnist ta problemy u suchasnykh umovakh [Formation of sustainable land use and soil protection systems: relevance and problems in modern conditions]. Ukrainian Geographical Journal, 3, 56-60 [In Ukrainian].

14. Ulko, Ye., Kucher, A., Salkova, I. \& Priamukhina, N. (2018). Management of soil fertility based on innovative approaches to evaluation of arable land: case of Ukraine. Journal of Environmental Management and Tourism. IX, 7(31), 1559-1569. doi: 10.14505/jemt.9.7(31).18

15. Baliuk, S.A., \& Miroshnychenko, M.M. (2019). Zemli potribna ne polityka, a zvazhenist, kompetentnist ta vidpovidalnist [The land does not need politics, but prudence, competence and responsibility]. Uriadovyi kur'ier, 242, 7 [In Ukrainian].

16. Baliuk, S.A., \& Truskavetsky, R.S. (2019). Beztsinnyi hruntovyi resurs Ukrainy - pid osoblyvyi kontrol derzhavy. Ryzyky ta ochikuvannia vid rynku zemel [Invaluable soil resource of Ukraine - under special state control. Risks and expectations from the land market]. Holos Ukrainy, 237 (7243), 1213 [In Ukrainian].

17. Baliuk, S. A., Kucher, A. V., \& Solovey, V. B. (Eds.). (2015). Derzhavna tsilova prohrama "Velykomasshtabne obstezhennia gruntovoho pokryvu Ukrainy" (naukovo-orhanizatsiini osnovy) [State target program "Large-scale survey of the soil cover of Ukraine" (scientific and organizational bases)]. Kharkiv: Smuhasta typohrafiia. [In Ukrainian].

18. Baliuk, S.A., \& Medvedev, V.V. (Eds.) (2015). Kontseptsiia orhanizatsii $i$ funktsionuvannia monitorynhu gruntiv $v$ Ukraini z urakhuvanniam yevropeiskoho dosvidu (naukove vydannia) [Concept of organization and functioning of soil monitoring in Ukraine taking into account the European experience (scientific publication)]. Kharkiv: Smuhasta typohrafiia. [In Ukrainian]. 